\title{
Status quo of soil petroleum contamination and evolution of bioremediation
}

\author{
Du Weidong ${ }^{1 \S}$, Wan Yunyang ${ }^{1,2}$, Zhong Ningning ${ }^{1 *}$, Fei Jiajia ${ }^{1}$, Zhang \\ Zhihuan $^{1}$, Chen Lijun² and Hao Jiming ${ }^{2}$
}

\author{
${ }^{1}$ State Key Laboratory of Petroleum Resource and Prospecting, College of Geosciences, China University of Petroleum, \\ Beijing 102249, China \\ ${ }^{2}$ Department of Environmental Science and Engineering, Tsinghua University, Beijing 100084, China
}

(C) China University of Petroleum (Beijing) and Springer-Verlag Berlin Heidelberg 2011

\begin{abstract}
Along with the rapid development of oil industries internationally, petroleum prospecting and exploitation activities are growing intensively. Especially in China, with the fastest economic growth in the world and shortage of petroleum resources, we are leading the practices of petroleum deep exploitation. Obviously, the risk of damage to the natural environment from these activities is high. Oil contamination in soils and groundwater is becoming a big issue along with pesticide pollution, which makes organic pollution prevention and control (OPPC) much more complex. In this paper, based on recent research on oil-contaminated soil at home and abroad, we make comments on the remediation technologies for polluted soil, emphasizing bioremediation techniques and degradation mechanisms in order to push forward research into bound organic pollution prevention and control (OPPC), especially in China.
\end{abstract}

Key words: Soil pollution, crude oil, bioremediation, organic pollution, biotransformation, polycyclic aromatic hydrocarbons

\section{Introduction}

In the last thirty years, petroleum prospecting, exploitation and refining activities have soared with the rapid increasing development of oil industries, synchronously with China's world-leading economic growth. Simultaneously, the environment pollution is catching the public's and scientists' attention because the limited resources inland force the petroleum and petrochemical industries into profound exploitation to meet China's oil thirst. For example, wells are being drilled at higher temperatures and at deeper depths, and adding much more drilling mud additives increased from the former 20 types to more than 100 types (but it was out of this paper's scope), leaving us to face increasingly higher pressure for environment protection. Though oil pollution in soil and groundwater was reported in the beginning of 1940s, the issues have been only paid serious attention in China in recent years, one big pollution problem after pesticide pollution. Recently, most countries in the world begin to focus on bioremediation of oil-contaminated soil and groundwater to recover from polluted ecology and to protect their agriculture and living environment, while avoiding secondary pollution.

\footnotetext{
* Corresponding author. email: nnzhong@cup.edu.cn

$\S$ as co-first author contributed equally to this work.

Received March 3, 2011
}

\section{The petroleum-caused pollution in the soil and its sources}

Processes in oil industries, mainly including prospecting, exploitation, gathering and transportation, refining, and even sales and trading of oil products, cause different kinds and extents of contamination to the surrounding soils (Fig. 1). These are generally classified into three sorts: pollution from prospecting and exploitation, pollution from petroleum and petrochemical industries' production and those from facilitating and auxiliary processes (Chen, 2005). We could cover a large range of chemicals, such as variable additives and auxiliaries, but in this paper, we focus on the pollution of petroleum (consisting components of saturates, aromatics, resins, asphaltenes, and unresolved complex mixture (UCM or hump)). It is obviously and publicly accepted that aromatics (such as benzene, toluene, ethylbenzene and xylenes (BTEX) and polycyclic aromatic hydrocarbons (PAHs)) pose high risks of ecological and environmental toxicity (He et al, 2009). Asphaltenes and UCM are similarly or much more harmful, especially if they are weathered (unpublished data).

Now, the issues about the solid wastes of oilfields (including both oil- and gas-fields in this paper) have provoked public recognitions and the dangerous wastes are entirely listed in the National Hazardous Waste Inventory (CMEP and NDRC, 2008). The emission solid sources in 


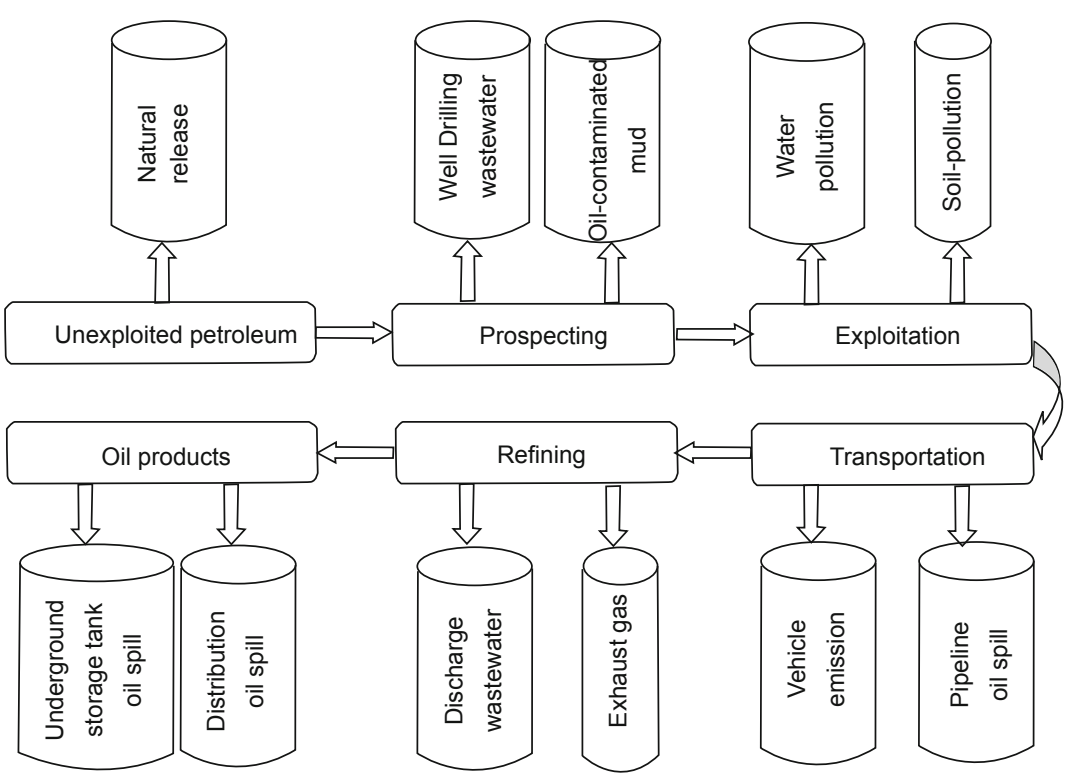

Fig. 1 Process Flows and discharges of waste materials in petroleum industries

oilfields mainly include fugitive/organized drilling waste mud (DWM), rock debris (RDs), crude oil-contaminated soil (COCS), oil sludge and oil sandstones (OSOS) (Table 1). For example, the basic compositions of oily solid waste in Jidong Oilfield are: water $(5 \%-30 \%)$, oil $(5 \%-21 \%)$, solid $(60 \%-90 \%$ that includes clay $(28 \%-58 \%)$, sand particles $(14 \%-39 \%)$, grits and steel slag $(21 \%-28 \%)$. For this kind of oil, the physical parameters of its heavy oil fractions are: initially boiling point $270{ }^{\circ} \mathrm{C}, 309{ }^{\circ} \mathrm{C}$ of $10 \%$ distillates, 336 ${ }^{\circ} \mathrm{C}$ of $20 \%$ distillates, colloid and asphaltene (25.7\%) with density of $941 \mathrm{~kg} / \mathrm{m}^{3}\left(20{ }^{\circ} \mathrm{C}\right)$, and viscosity of $394 \mathrm{mPa} \cdot \mathrm{s}(40$ ${ }^{\circ} \mathrm{C}$ ). According to the data above, the amount of oil in the solid waste is very high, and it can be not only chemically cleared away, but also microbially degraded (Sun et al, 2003).

\begin{tabular}{|c|c|c|c|}
\hline Solid wastes & Characteristic description & Source & $\begin{array}{l}\text { Yield (ten thousand ton/year)/ } \\
\text { Emission ratio, \% }\end{array}$ \\
\hline Drilling waste mud & $\begin{array}{c}\text { Oily, } \mathrm{COD}, \mathrm{Cr}^{6+}, \mathrm{Pb}^{2+}, \mathrm{Cd}^{2+} \text {, polymer materials, } \\
\text { abnormal } \mathrm{pH}\end{array}$ & $\begin{array}{l}\text { Formation change; discarded after } \\
\text { drilling completion; leaked in the } \\
\text { mud circulatory system }\end{array}$ & $100 / 40$ \\
\hline $\begin{array}{c}\text { Rock cuttings \& } \\
\text { debris }\end{array}$ & Oily, $\mathrm{COD}, \mathrm{Cr}^{6+}, \mathrm{Pb}^{2+}, \mathrm{Cd}^{2+}$, polymer materials & Cutting brought back by the mud & $116 / 25$ \\
\hline $\begin{array}{l}\text { Crude oil- } \\
\text { contaminated soil }\end{array}$ & High concentrated oil & Spilling during operation; accidents & $70 / 10.5$ \\
\hline $\begin{array}{l}\text { Oil sludge and oil } \\
\text { sandstone }\end{array}$ & $\begin{array}{l}\text { Oil, sludge, sandstone and water }(99 \%) \\
\text { fully emulsified and not easily separated. } \\
\text { Complex trace components. }\end{array}$ & Transferring operation & $22 / 0.44$ \\
\hline Domestic waste & $\begin{array}{l}\text { Abandoned packaging, abandoned cotton yarn, } \\
\text { and thermal insulation and anti-freezing materials }\end{array}$ & Domestic waste & / \\
\hline
\end{tabular}

Three sources of drilling waste mud (DWM) are: (1) generated by the replacement of the mud system when the formation properties change; (2) disposed after drilling; (3) leaked in the mud circulatory system. The amount of DWM in oilfields can be up to $1000,000 \mathrm{t}$ each year, and the components are very complex (Table 1 ) because with the differences of drilling fluid systems, each type of drilling waste fluid (DWF) has its own characteristics. The drilling fluids used in various oilfields in China are mainly waterbased drilling fluids, oil-based drilling fluids and gas-based drilling fluids. Different types of drilling fluids contain different additives which consist of inorganic salts, heavy metals, oil-products and a lot of organic polymers (Du et al, 2011). Some of these components with high toxicity such 
as $\mathrm{Cr}$ are carcinogens, and public concerns have arisen. In China, the enterprise standard to detect the biological toxicity of drilling fluid and its waste for onshore oilfields has been enacted in 2004.

As far as oilfield prospecting and exploitation is concerned, crude oil-contaminated soils (COCS) are found around the oil pools, and some spills scattered near depot stations, others from the downhole operations, oil production testing, the fracturing and/or workover processes. It has been reported that totally the crude oil spilled to the ground is up to 2100-8400 tonnes each year in Daqing Oilfield (Qi and Wang, 2002). In addition, accidents (such as well blowouts or man-made sabotage) induced, unpredictable, sudden and emergency crude oil contamination cannot be ignored either (unpublished data). Oil sludge and oil sand (OSOS) from the cleaning processes of devices including transferring stations, united/jointing stations, oil tanks, settling tanks and/or others were usually composed of oil, oily sand with water content reached to $99 \%$, forming a fully emulsified mixture that is difficult to separate. The oil content of oily sludge is generally $10 \%-15 \%$. In the petrochemical industries of China, there are $800,000 \mathrm{t}$ bottom mud generated from tanks and pools annually. In Shengli Oilfield, that is more than 100,000 t, and about $150,000 \mathrm{t}$ in Dagang Oilfield, $5 \times 10^{4} \mathrm{~m}^{3}$ in the Henan Oilfield, relatively. Often the typical oily sludge is just piled up outdoor without any treatment. The percentage of oil, silt (solids with the particle size $>0.1 \mathrm{~mm}$ ) and water respectively is roughly $10 \%, 85 \%$ and $5 \%$, in which a lot of harmful and odorous components exist, such as benzene series, phenols, carboxylic acids, PAHs (such as anthracene and pyrenes), sulfides and nitrides. If it is disposed of inappropriately, the oily sludge will not only contaminate the environment, but also waste resources. It is always a tough problem in most oilfields (http://solidwaste. chinaep-tech. com/subject/oilsludge/8935. shtml). In terms of lots of old oilfields coming into the "Three-High" (high water-cut, high recovery, high production speed) exploitation periods, the production of oil sludge and oil sand proliferates, and it becomes increasing important to develop harmless, environmentally friendly and effective treatment technologies.

\section{The pollution situation of petroleum hydrocarbons in the soil and the progress of the treatment technologies}

Since the beginning of 1980 s, people have realized the seriousness of the issues about the petroleum hydrocarbons soil pollution (Atlas, 1981, 1984; Stegmann et al, 2001). Because of producing, transporting, storing and using petroleum products massively, soil has become seriously polluted since then in America (Kostecki and Calabrese, 1988). Presently, dry oily sludge amounts to $10,000,000 \mathrm{t}$ in America, and more than 6,600,000 t in Europe, and about 2,400,000 $t$ in Japan (Liu et al, 2004). In Netherlands, there are around 100,000 contaminated sites, with the polluted soil over $200 \mathrm{Mt}$ (Rulkens, 2001). In Russia, with the oil and the gas pipelines more than 1.5 million kilometers, there were about 700 massive leakage accidents (each spilling greater than or equal to 25,000 barrels) and more than 60,000 small ones annually. Just in Eastern Siberia, there was about 3-10 Mt oil leaked each year (Philp, 2005). In China, the situation is also not optimistic (Du et al, 2011). In order to dispose the pollutants and wastes, global emphases have been put on them for many years, accumulated rich experience, some of which has been used in the industrial stage combating these problems. Main measures taken are: 1) Leave it be for the soil that has been polluted, but keep it out of any utilities; 2) Completely or partly trap the polluted soil; 3) Excavate the contaminated soil, and refill with borrowed soil for amelioration; 4) treat in situ (for example without excavation) or ex-situ, that is to say on site or in a processing center. The main disposal methods include backfilling, reclamation, extrusion, solid-liquid separation, solidification and stabilization, incineration, recovery and utilization and biodegradation. Some specific processing techniques appear (Calabrese and Kostecki, 1992; Stegmann et al, 2001), such as carbon dioxide extraction, soil vapor extraction (SVE), bioventing (BV), bio-slurry(BS) and soil washing (SW)(Barlow and Philp, 2005; USEPA, 2001; He et al, 2006). Reviews on soil vapor extraction (SVE) (Li et al, 2001b) and bioventing (BV) (Sui et al, 2003) are available (Korda et al, 1997; USACE, 2002). Other new techniques and methods have been around, but cost-efficiency is one important factor for technique selections, and sometimes we have to make compromising decisions between them. Table 2 shows the costs of various techniques used for soil remediations. It should be noted that the cost was varied not only with different techniques but also with various factors of solid conditions. Because of limited cases, cost data and so-called "commercial secrets", the cost evaluation could be exclusively a reference of an actual application.

In the Exxon Valdez oil spill, it cost one million dollars each day just for cleaning the oil-polluted rocks with water, not to mention physical cleaning, however, instead, the cost of bioremediation for the several hundreds of kilometers coastline was totally no more than one million dollars. According to variously statistical reports, the costs of various bioremediation are varied from one case to another, generally between USD 2 and 268 per ton, having advantages both price and environmental benefits, compared to physical and chemical methods. Looking at the total market value and the taxation proportion of remediation market, we can see that the bioremediation market is expanding (Table 3 and Fig. 2), which indicates that people are optimistic about the prospects of this technique around the world.

Due to increasing public attention to environmental qualities and the demand of environment protection, the bioremediation market is expanding gradually. In 1997, the total bioremediation market value was 870 million dollars, which soared to $\$ 1.1$ billion in 2002 . Even so, it just accounted for less than $10 \%$ of the total cost for market remediation that is 25 billion although the data varies among different reports (Boopathy, 2000; Ward, 2004), but which means it still has a broader development space. 
Table 2 Costs of various soil-remediation techniques

\begin{tabular}{|c|c|c|c|}
\hline Remediation & $\operatorname{Cost}^{\mathrm{a}}$, ton & Cost $^{b}, \mathrm{~m}^{3}$ & Comments \\
\hline Excavation/disposing ex-situ & $7-50$ & $53-134$ & Simple but with long processing procedures \\
\hline Soil washing & $50-250$ & $26-71$ & $\begin{array}{l}\text { For poor and/or dry soil, water consuming, higher } \\
\text { after cost }\end{array}$ \\
\hline Physicochemical cleaning & $50-170$ & $200-300^{c}$ & For poor and/or dry soil, solvent consuming \\
\hline in situ stabilization/solidification & $60-100$ & $17-178$ & Destroy soil structure \\
\hline in situ electrokinetic technique & $40-120$ & & Since 1980 s, automatic, power consuming \\
\hline Engineering seal-capping & & $26-62$ & Without eliminating pollution \\
\hline Bio-slurry & $50-80$ & & \\
\hline Biopile & $15-45$ & & \\
\hline Land farming & $10-100$ & & \\
\hline Turning over dry windrow & $5-60$ & & \\
\hline in situ chemical oxidation & & $71-152$ & Probably producing by-products, such as DBPs \\
\hline Biotreatment in situ & $5-160$ & & Relative longer time \\
\hline Bioventing & $15-80$ & & Highly stable and trustable \\
\hline Thermal treatment & $40-700$ & 178-715(incineration in site) & $\begin{array}{l}\text { Heating speed slowly, complete/ loses most } \\
\text { soil functions }\end{array}$ \\
\hline Incineration & $50-1200$ & $400-1200^{\mathrm{c}}$ & $\begin{array}{l}\text { Destroying soil functions, causing } \\
\text { secondary pollution }\end{array}$ \\
\hline Lime/concrete/volcanic ash solidification & $20-170$ & & Pollution was not eliminated \\
\hline Solvent extraction & $30-600$ & & Massively consuming solvents \\
\hline Encapsulation with plastic membrane & & $71-107$ & Probably inducing new pollutants \\
\hline Kiln-based vitrification & $30-500$ & & High energy-consuming \\
\hline
\end{tabular}

Notes: a- UK in 1997, unit: pound (£), modified from (Barlow and Philp, 2005);

b- Industrial Market Researches of MSI, unit: US dollar (\$), modified from (Philp, 2005); c- unit: ton

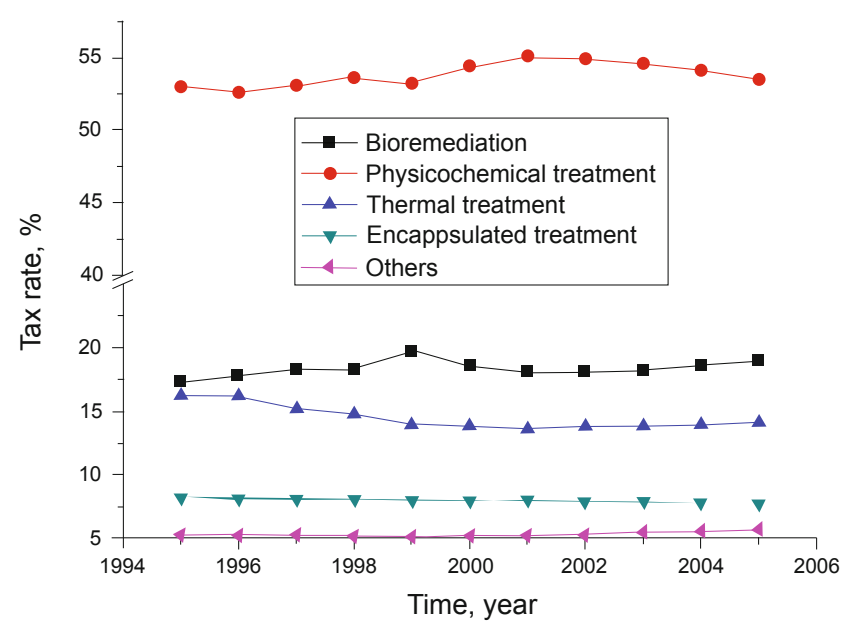

Fig. 2 Remediation markets of polluting fields in Europe
Table 3 The bioremediation markets in the world

\begin{tabular}{cccc}
\hline \multirow{2}{*}{ Markets } & \multicolumn{3}{c}{ Dollar/million } \\
\cline { 2 - 4 } & 1994 & 1997 & 2000 \\
\hline United States of America & $160-450$ & $225-325$ & $375-600$ \\
Europe & $105-175$ & $180-300$ & $375-600$ \\
\multicolumn{1}{c}{ Germany } & $70-100$ & $100-150$ & $250-350$ \\
Netherlands & $10-20$ & $15-35$ & $30-60$ \\
Scandinavia & $10-20$ & $15-35$ & $30-60$ \\
England & $5-10$ & $7.5-20$ & $15-30$ \\
Others & $10-25$ & $42.5-60$ & $50-100$ \\
Canada & $15-35$ & $30-50$ & $50-100$ \\
\hline
\end{tabular}




\section{The biological techniques in the treatment of oil-contaminated soils}

Among various remediation techniques, the biological treatment (biotreatment) no doubt at present is the researchers' highlight and top priority. Biotreatment is a controlled and spontaneous process that uses organisms, especially microorganisms for biocatalytic degradation of environmental pollutants to decrease or eventually destroy them. It is an emerging technique for environmental protection which is based on microorganism degradation and represents the development direction of future (Shen, 2000). The advantages of biological techniques are as follows (Agathos and Reineke, 2002; Fass et al, 1999; Ward, 2004): (1) The pollutants are degraded and cleared up on site; (2) It is very simple and interferes little with the surroundings for on-site processing; (3) Least cost, which just accounts for $30 \%-50 \%$ of those of the traditional chemical and physical remediations; (4) The possibility that people are exposed directly to the pollutants is significantly reduced; (5) There is no or less secondary pollution and consequent problems.

Although this method which has provoked international attention is just in its preliminary stage at present, with the increasing severity of the pollution and the seriousness of the environmental protection situation, the disadvantages of traditional ways show up gradually. In 1989, the bioremediation techniques have successfully been used to help dispose of oil spilled from the giant oil tanker "Exxon Valdez" on the coast of Alaska (until the 2010 Deepwater Horizon oil spill, the Exxon Valdez spill was the largest and most hazardous ever in USA waters (NIH and NLM, 2010; USEPA, 2009)). For the first time in the United States of America, bioremediation research began to be the hotspot and cutting edge of environment science, at least in bound fields. In 1997, 1.2 Mt soils was remediated via bioremediation in Germany, which accounted for $55.8 \%$ of all repairing amount remediation $(850,000$ tons remediated by chemical/physical ways, 100,000 tons by thermal treatment) (Miehlich, 2001). Comparing with thermal treatment (which mostly loses all the soil functional diversity) or washing (just for dry and barren soils) (Table 2), natural/intrinsic remediation which organisms play main roles has been paid great attention in scientific communities, because of its extensive applicability and limited adverse side effects.

In nature, microorganisms which can degrade oil exist widely in soil, ground water, oceans and lakes. Many of them can live with oil as their only carbon source. Now more than 70 genera and 200 strains have been found that can oxidatively biodegrade one or more types of petroleum hydrocarbons (Englert et al, 1992; Feng et al, 2007; Li et al, 2001a; Li and Feng, 1991; Liang et al, 2005). Some of bacterial and fungal genera (Chaineau et al, 1999; 1995; Korda et al, 1997; Pointing, 2001) reported in the literature are listed in Table 4. In addition, some algae can biodegrade oils as well (Semple et al, 1999; Walker et al, 1975). It should be pointed that enhanced bioremediation through rhizosphere interactions (Su and Yang, 2009; Toyama et al, 2011) is also very important but this is at its early stages and needs further investigation (Robertson et al, 2007; Wan, 2011a).

Comparison with physical and chemical methods, although having its weak points, the advantages of biotreatments (Table 2 and Table 5) are obvious, (Agathos

Table 4 Some of reported microorganism genera that can biodegrade petroleum hydrocarbons

\begin{tabular}{|c|c|c|c|}
\hline \multicolumn{2}{|c|}{ Bacterium } & \multicolumn{2}{|c|}{ Fungus } \\
\hline Achromobacter & Pseudomonas & Acremonium & Humicola \\
\hline Acinetobacter & Pseudobacterium & Aspergillus & Monilia \\
\hline Aeromonas & Rhodococcus & aureobasidium & Mortierella \\
\hline Agrobacterium & Sarcina & Basidiomycete & Paecilomyces \\
\hline Alcaligenes & Serratia & Beauveria & Penicillium \\
\hline Arthrobacter & Spirillum & Candida & Phoma \\
\hline Bacillus & Streptomyces & Chrysosporium & Pichia \\
\hline Brevibacterium & Vibrio & Cladosporium & Rhodotorula \\
\hline Chromobacterium & Xanthomonas & Cochliobolus & Saccharomyces \\
\hline Coryhebacterium & & Cryptococcus & Scolecobasidium \\
\hline cytophaga & & Cylindrocarpon & Selenotila \\
\hline Desulfovibrio & & Debaryomyces & Sporobolomyces \\
\hline Erwinia & & Endomyces & Spicaria \\
\hline Flavobacterium & & Fusarium & Tolypocladium \\
\hline Micrococcus & & Geotrichum & Torulopsis \\
\hline Micromonospora & & Gliocladium & Trichoderma \\
\hline Mycobacterium & & Gongronella & Trichosporon \\
\hline Nocardia & & Graphium & Verticillium \\
\hline Proteus & & Hansenula & \\
\hline
\end{tabular}

Table 5 The comparison of common treatment approaches for oil pollutants

\begin{tabular}{|c|c|c|}
\hline Treatment approaches & Advantages & Disadvantages \\
\hline Physical & Destroy most pollutants & $\begin{array}{l}\text { Need devices/equipment at high cost of destruction of soil } \\
\text { diversity and energy consuming }\end{array}$ \\
\hline Chemical & Good at high efficiency of oil removal & Produce secondary pollutions at high cost \\
\hline Biological & $\begin{array}{l}\text { 1) High efficiency of oil removal } \\
\text { 2) Low energy, low cost } \\
\text { 3) Little impact to environments, no or less } \\
\text { secondary pollutions } \\
\text { 4) Wide applicable ranges } \\
\text { 5) High public acceptability }\end{array}$ & $\begin{array}{l}\text { 1) No accessible to some artificial pollutants } \\
\text { 2) Special microorganisms just biodegrade the specific pollutants } \\
\text { 3) Easily affected by surrounding conditions } \\
\text { 4) Possibly with residues } \\
\text { 5) No oil could be recycled }\end{array}$ \\
\hline
\end{tabular}


and Reineke, 2002; Fass et al, 1999). It will be the sole choice if other methods are not accessible.

Oil is a highly complicated mixture with a combination of hydrocarbons consisting predominantly of aliphatic, alicyclic and aromatic hydrocarbons, and small amounts of nitrogen, oxygen, and sulfur compounds (NOS components), trace amounts of metals and/or metallic compounds. Until now some components are bulked as unresolved complex matter
(UCM) (Table 6). Though it is still too early to understand the real-time and in-situ mechanisms of oil degradation, quite a lot of research has been done on the mechanisms of several typical components, such as the predominant components of alkanes, alicyclic hydrocarbons, aromatics and polycyclic aromatic hydrocarbons (Semple et al, 1999), and possible pathways of biodegradation of these compounds have been recently reviewed (van Hamme et al, 2003).

Table 6 Bio-transformable organic molecular fragments and microbial dissociation

\begin{tabular}{|c|c|c|c|c|}
\hline $\begin{array}{l}\text { Molecular } \\
\text { fragment }\end{array}$ & Organic molecular fragment & $\begin{array}{l}\text { Molecular } \\
\text { fragment }\end{array}$ & $\begin{array}{l}\text { Organic } \\
\text { fragment }\end{array}$ & Structure \\
\hline $\mathrm{C}-\mathrm{OH}$ & Alcohol & $\mathrm{R}-\mathrm{N}=\mathrm{N}^{+}=\mathrm{N}^{-}$ & Organicazide & \\
\hline \multirow[t]{2}{*}{$-\mathrm{CHO}$} & Aldehyde & $\mathrm{RCONH}_{2}$ & Amide & $\mathrm{NH}_{2}$ \\
\hline & Alicyclic hydrocarbon & $\mathrm{R}_{4} \mathrm{~N}^{+}$ & Quatenary amine & \\
\hline $\mathrm{C}-\mathrm{CH}_{2-}$ & Saturated aliphatic comound & $\mathrm{R}_{1}\left(\mathrm{R}_{2}\right) \mathrm{NR}_{3}$ & Amine & $\begin{array}{l}\cdots, R_{1} \\
\hat{N}_{1}^{\prime} \\
\mathrm{R}_{2}\end{array}$ \\
\hline$-\mathrm{CH}=\mathrm{CH}-$ & Unsaturated aliphatic compound & Cyclic amide & $(\alpha \sim \varepsilon)$ lactam & $\mathrm{IH}_{2}$ \\
\hline & (simple substituted)Aromatic & $\mathrm{R}-\mathrm{C} \equiv \mathrm{N}$ & Nitrile & \\
\hline & Heterocyclic aromatic & $\mathrm{C}-\mathrm{NO}_{2}$ & Nitrile & \\
\hline$-\mathrm{COOH}$ & Carboxylic acid & $\mathrm{R}_{1} \mathrm{~N}\left(-\mathrm{R}_{2}\right)-\mathrm{N}=\mathrm{O}$ & Nitrosocompound & \\
\hline & $\begin{array}{l}\text { Polycyclic aromatic } \\
\text { hydrocarbon }\end{array}$ & $\mathrm{R}_{3} \mathrm{C}(=\mathrm{O}) \mathrm{NR}_{1}\left(\mathrm{R}_{2}\right)$ & N-substituted amide & $\prod_{\mathrm{O}}^{\mathrm{N}_{1}} \mathrm{R}_{\mathrm{R}_{2}}$ \\
\hline$-\mathrm{RCOOCR}$ & $>\mathrm{RC}(\mathrm{O}) \mathrm{OH}$ & $\mathrm{R}-\mathrm{CO}-\mathrm{NH}-\mathrm{OH}$ & Hydroxamic acid & $\overbrace{\mathrm{H}}^{\mathrm{R}} \mathrm{OH}$ \\
\hline $\mathrm{RC}-\mathrm{O}-\mathrm{CR}$ & $\begin{array}{c}\text { ArOR--ArOH; } \\
\mathrm{ROCH}_{2} \mathrm{R}^{\prime}--\mathrm{ROH}\end{array}$ & $-\mathrm{NH}_{2}-\mathrm{OH}$ & Hydroxylamine & \\
\hline $\mathrm{C}_{6} \mathrm{H}_{7}(\mathrm{OH})_{4} \mathrm{OR}$ & OR & $\mathrm{R}_{1}\left(\mathrm{R}_{2}\right)=\mathrm{NOH}$ & Oxime & $\mathrm{N}^{\mathrm{OH}}$ \\
\hline $\mathrm{RX}$ & $\mathrm{R}=$ carbon atoms & $\mathrm{R}_{1}-\mathrm{CS}-\mathrm{NR}_{2}\left(\mathrm{R}_{3}\right)$ & Thioamine & \\
\hline $\mathrm{C}-\mathrm{Si}-$ & Organosilicone & $\left(\mathrm{NH}_{2}\right)_{2} \mathrm{CO}$ & Urea & \\
\hline C-As bond & Organoarsenicals & & $(\alpha \sim \varepsilon)$ lactone & \\
\hline & $\mathrm{H}_{2} \mathrm{Ne}_{\mathrm{NH}_{2}}^{\mathrm{Se}}$ & $\mathrm{R}-\mathrm{C}(=\mathrm{O})-\mathrm{R}$ & Ketone & $\mathrm{O}$ \\
\hline $\mathrm{C}-\mathrm{P}$ bond & Organophosphorous compound & $\mathrm{R}-\mathrm{S}(=\mathrm{O})_{2}-\mathrm{OH}$ & Sulfonic acid & \\
\hline C-Sn bond & Organotin & $\mathrm{R}-\mathrm{SH}$ & Thiol & \\
\hline $\mathrm{R}-\mathrm{O}-\mathrm{SO}_{2}-\mathrm{O}-\mathrm{R}$ & Organic sulphate & & Heterocyclic compound & \\
\hline
\end{tabular}

$\mathrm{C}-\mathrm{Hg}$ bond $\quad$ Organomecuricals $\quad-\mathrm{C}-\mathrm{Te}-\mathrm{C}-\quad$ (Dimethyl)telluride

Abbreviation: $\mathrm{R}$ (including those $\mathrm{R}_{1}, \mathrm{R}_{2}, \mathrm{R}_{3}$ with same or different groups)-organic fragment; Ar-aryl group; Alk-alkyl group;

Het-heterocyclic group; $\mathrm{X}$-halogen atom. The abbreviations in Table 7 are same with these. 


\section{(1) Degradation of normal alkanes}

General recognition at present believes that the normal alkanes with carbon atoms up to about 44 (Haines and Alexander, 1974) can be oxidized via monoterminal and/or diterminal oxidation which can also be named as $\omega$-oxidation and sub-terminal oxidation. The alkane $(n-\mathrm{C})$ first was usually oxidized to be primary alcohol via terminal-oxidation, then to an aldehyde and a carboxylic acid. Carboxylic acids are further transformed to acetyl coenzyme A (AcCo A) and shorter dicarboxylic acids (by removal of carbon dioxide) via $\beta$-oxidation. The chain-length of dicarboxylic acids is continuously decreased to become two-carbon acetic acid (Atlas, 1981; Singer and Finnerty, 1984). Acetic acid is broken off from the alkane chains and finally decomposed to carbon dioxide via the central metabolic pathway. Alkanes with branched chains can be biodegraded by $\alpha$-oxidation, $\omega$-oxidation and/or $\beta$-basic groups elimination, although the branched chains can increase the resistance at certain degrees to be oxidatively degraded by microorganisms (Singer and Finnerty, 1984; Xia et al, 2006; Wang and Wen, 2000) (Fig. 3).

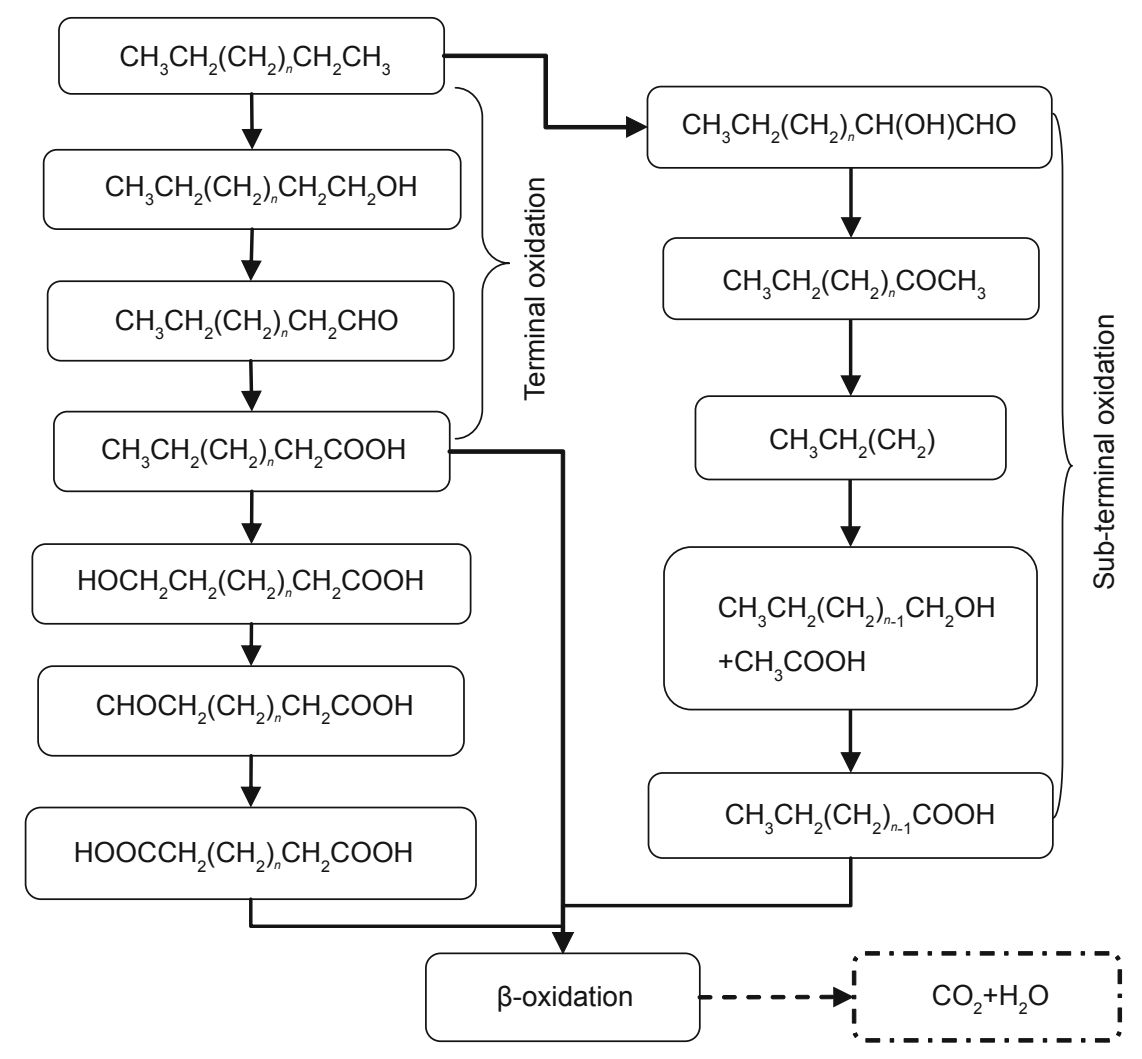

Fig. 3 The aerobic biodegradation processes of $n$-alkanes

The biodegradation of alkanes of petroleum hydrocarbons can be concisely summed up as:

$\mathrm{C}_{n} \mathrm{H}_{2 n+2} \rightarrow \mathrm{C}_{n} \mathrm{H}_{2 n+1} \mathrm{OH} \rightarrow \mathrm{C}_{n} \mathrm{H}_{2 n-1} \mathrm{CHO} \rightarrow$ aliphatic acids $\rightarrow \mathrm{CH}_{3} \mathrm{COOH}$ via $\beta$-oxidation $\rightarrow \mathrm{CO}_{2}+\mathrm{H}_{2} \mathrm{O}+$ biomass

\section{(2) Degradation of cyclic hydrocarbons}

Cyclic hydrocarbons are any chemical compounds with one or more rings of carbon atoms in the chemical structure of their molecules, including cycloalkanes, aromatics and heterocyclic compounds. Cycloalkanes (naphthenes) exist extensively in the biosphere and crude oil (in the boiling range of 40 to $200{ }^{\circ} \mathrm{C}$, with a content of $20 \%$ to $70 \%$; in the boiling range of $350-500{ }^{\circ} \mathrm{C}$, with a content up to $50 \%-60 \%$ ) (Perry, 1984), but most often they can be ignored easily. Presently, it is believed that the degradation of cycloalkanes is similar to the sub-terminal degradation pathways of alkanes (paraffins). Many microorganisms which can oxidize the acyclic alkanes can also hydrolyze the naphthenic hydrocarbons because of their broad specificity.
Actually, co-metabolisms of naphthenic hydrocarbons are much more common because of lack of microorganisms in nature those can consume naphthenic hydrocarbons directly (Perry, 1984). Hydroxylation is the crucial stage for the degradation of these compounds. As shown in Fig. 4, steroids, cyclic terpenes, indane (benzocyclopentane) and cyclohexane all have similarly metabolic processes. The intermediates in the pathway of cyclohexane biodegradation includes cyclohexanol, cyclohexanone, $\varepsilon$-caprolactone, and then open loop to generate hydroxycarboxylic acid. The processes between cyclohexane and cyclohexanol (or cyclic alcohols in other conditions) have the relationships of cometabolism (Fig. 4) (Atlas and Bartha, 1998). To the alkylsubstituted alicyclic compounds, two initial positions that can be potentially oxidized are on the side chains and the alicyclic rings, which can be affected by properties of compounds, genera of microorganisms, and others factors. Research into the typical biodegradation of naphthenic acids found that the naphthenic acids with substituent groups were biodegraded much more slowly than those unsubstituted (Clemente and 


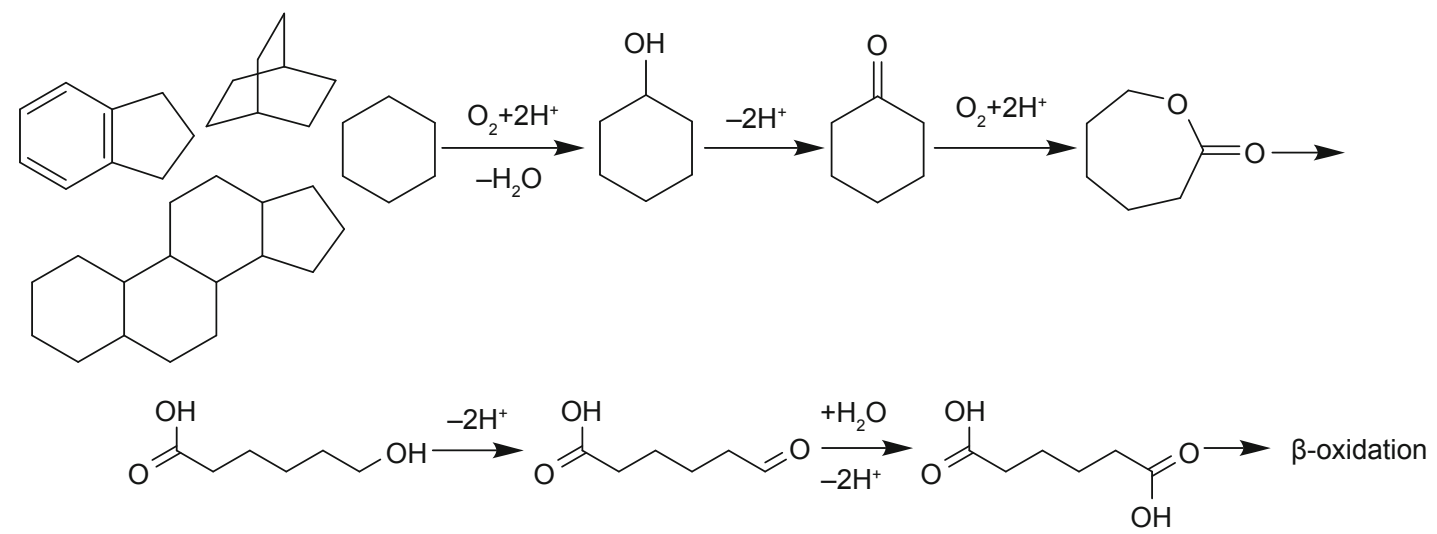

Fig. 4 Aerobic degradation reactions of cyclic hydrocarbons

Fedorak, 2005).

\section{(3) Degradation of arenes}

Fungi and microorganisms (bacteria and archaea) can oxidize aromatic substrates from benzene to benzanthracene. Initially, bacteria incorporate the two oxygen atoms of an oxygen molecule to substrates under enzymatic oxidation of dioxygenase, oxidizing arenes to cis-dihydrodiphenols. The cis-dihydrodiphenol can be further oxidized to catechols which will be further oxidatively decomposed by another dioxygenase which can cleave aromatic rings. On the contrary, fungi oxidize the arenes to trans-configuration dihydrodiphenol under the enzymatic degradation of monooxygenase and cyclohydrolase. The typical pathways of microbial degradation of typical arenes are shown in Fig. 5 (revised from Cerniglia, 1984), actually which could be the prime differences between prokaryotes and eukaryotes response to environmental pollutants (xenobiotics) (Wackett and Hershberger, 2001; Su et al, 2001; Jin, 1997). Anaerobic degradation of arenes has been recently invoked as the most important in deep subsurface oil degradation (Head et al, 2003; Jones et al, 2008; Roling et al, 2003), but it is beyond the scope of this paper because the oil pollution mostly happens on the earth's surfaces where aerobic reactions are thought to be predominant (Venosa et al, 2010). The aerobic degradation which takes place in petroleum hydrocarbons forms a diphenol intermediate (Fig. 5, upper right), and one of the anaerobically degrading intermediates of BTEX is benzoylcoenzyme A (Wackett and Hershberger, 2001) (Fig. 5 , lower right) and then it can be further degraded to cyclic acids (Aitken et al, 2004).

\section{(4) Degradation of polycyclic aromatic hydrocarbons}

Naphthalene is the simplest PAH. Initially, it is catalyzed by dioxygenase to produce cis-naphthalene dihydrodiol (1), then it will be dehydrogenated to produce 1,2-dihydroxynaphthalene (2). The cis-Ohydroxyl benzalacetone acid (4) may be generated from 2-hydroxychromene-2-carboxylic acid (3) by its isomerase (Philp, 2005). The compound 4 is further cleaved of the side-chain pyruvate (5) to form salicylaldehyde (6) and salicylic acid (7). The salicylic acid is further transformed to catechol (8) or gentisic acid (2,5-dihydroxybenzoic acid) (9) by different enzymes, which separately enters into the analogous metabolic pathway of nitrobenzene metabolism or intermediary metabolism (Fig. 6). Fluorene and anthracene and some heterocyclic compounds or derivatives are biodegraded with similar pathways via compound 7 (Fig.

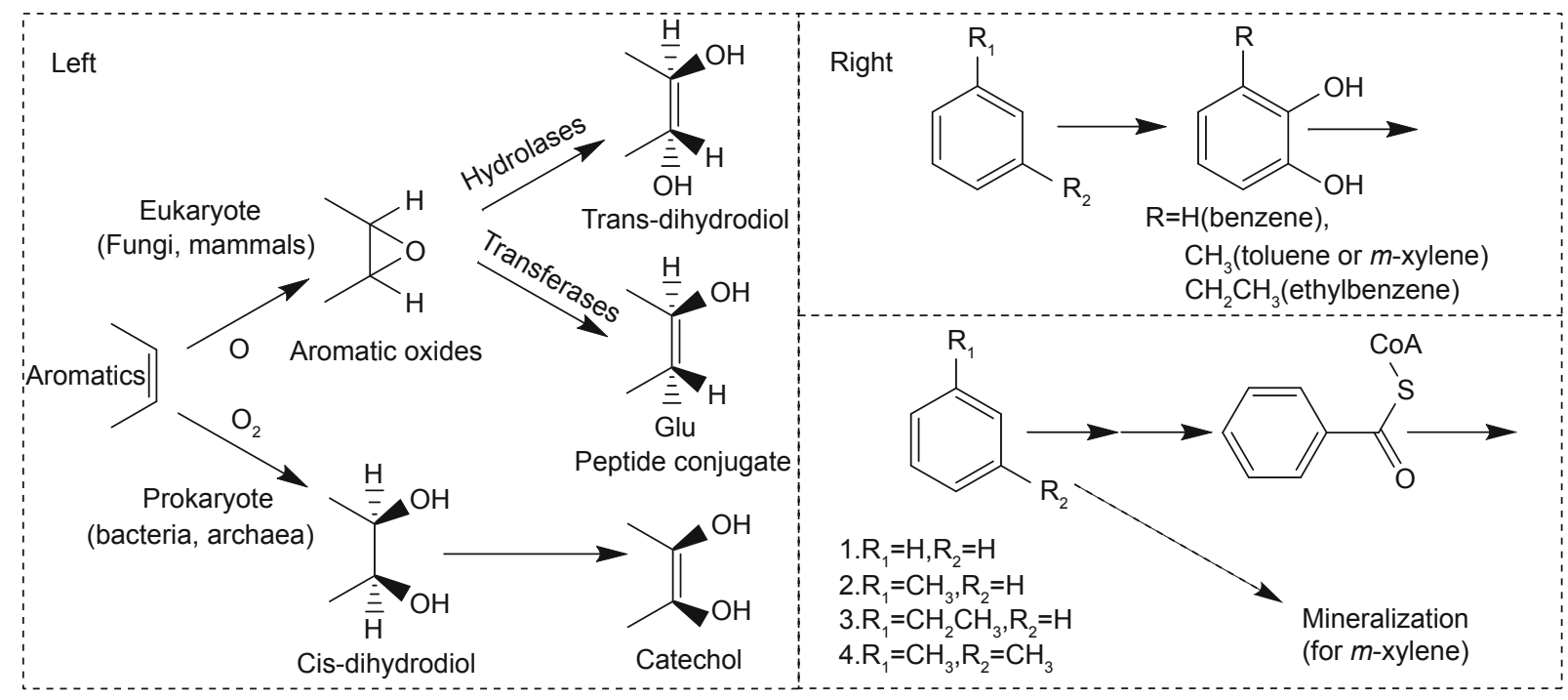

Fig. 5 The aerobic (left and upper right) and the anaerobic ( lower right) reactions of aromatic hydrocarbons. Right, 1: benzene, 2: methylbenzene, 3: ethylbenzene, 4: m-xylene 
6). Many kinds of enzymes are involved in the metabolic processes (Fig. 5 and Fig. 6).

Three ring PAHs have similar biodegradation processes. The first step is still to generate cis-dihydrodiol by dioxygenase catalysis, then dehydrogenation to the corresponding diol. Thirdly, one ring is oxidatively decomposed to a side chain which is further cleaved from the rings. The remaining degradation of two ring diol goes as the way of naphthalene described above (Fig. 6) to catechol and/ or gentisic acid until they are absolutely degraded.
As for four- or greater ring PAHs, the catabolic metabolism processes are unclear yet, but the initially oxidative process is similar. The following induction of biodegradation are general rules which refer to the majority of PAHs.

In both aerobic and anaerobic conditions, the degrees of biodegradable ease/difficulty are dependent on the properties of PAHs, such as solubility, numbers of rings, type and position and number of substituent groups and properties of any heteroatoms (common in NOS) (Cookson, 1995;

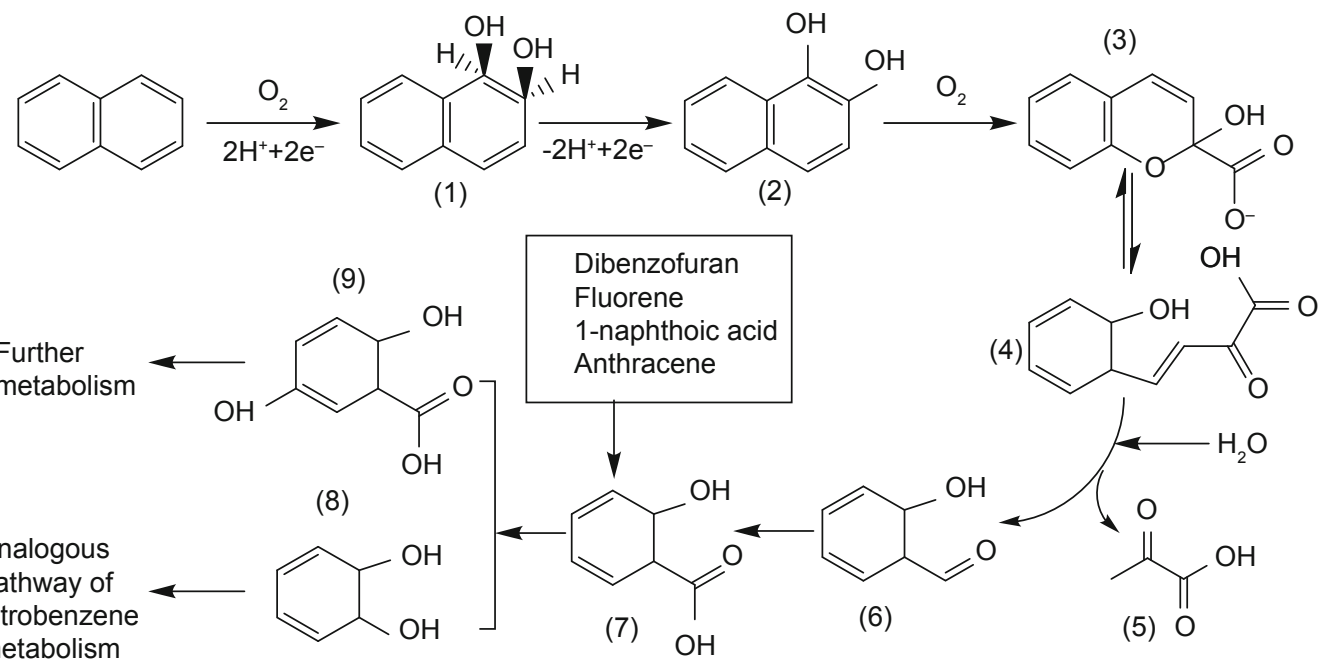

Fig. 6 The aerobic degradation of naphthalene and other analogous compounds by bacteria

Wackett and Hershberger, 2001). Generally speaking (Fig. 7), (1) there are distinctly different biodegradations of various microorganisms to different PAHs. (2) Usually, two or three ring PAHs can be degraded easily by bacteria. (3) Four or five ring PAHs are resistant to biodegradation, and some are even tend to persistent. (4) Adding three methyls to the structure of benzene ring seriously reduces the biodegradability. (5) Increasing the saturation of PAHs will significantly reduce the biodegradability. (6) Biodegradation of PAHs of four/five or more rings is dependent on co-metabolism with their analogies. (7) The bio-synergy and bio-diversity of microorganisms are beneficial to biodegradation and bioremediation. (8) The rate of the incipient oxidation of rings is a crucial step, and subsequent steps go rapidly for three or more ring PAHs. (9) Adding PAHs-oxidizing bacteria to the pollution sites probably increase the biodegradation speed and favors bioremediation. (10) The anaerobic degradation of PAHs has not been extensively studied and no uses on sites are reported yet. (11) PAHs with two or three rings can be transformed in the conditions of denitrification, sulfate reducing, methanogenesis or fermentation.

Generally, the biodegradation process for oil can be expressed as the formula:

Oil products + bacteria/fungi $+\mathrm{O}_{2} / \mathrm{H}_{2} \mathrm{O}$ (aerobic/anaerobic) + nutrients $\rightarrow \mathrm{CO}_{2}+\mathrm{H}_{2} \mathrm{O} / \mathrm{CH}_{4}+$ by-products + biomass

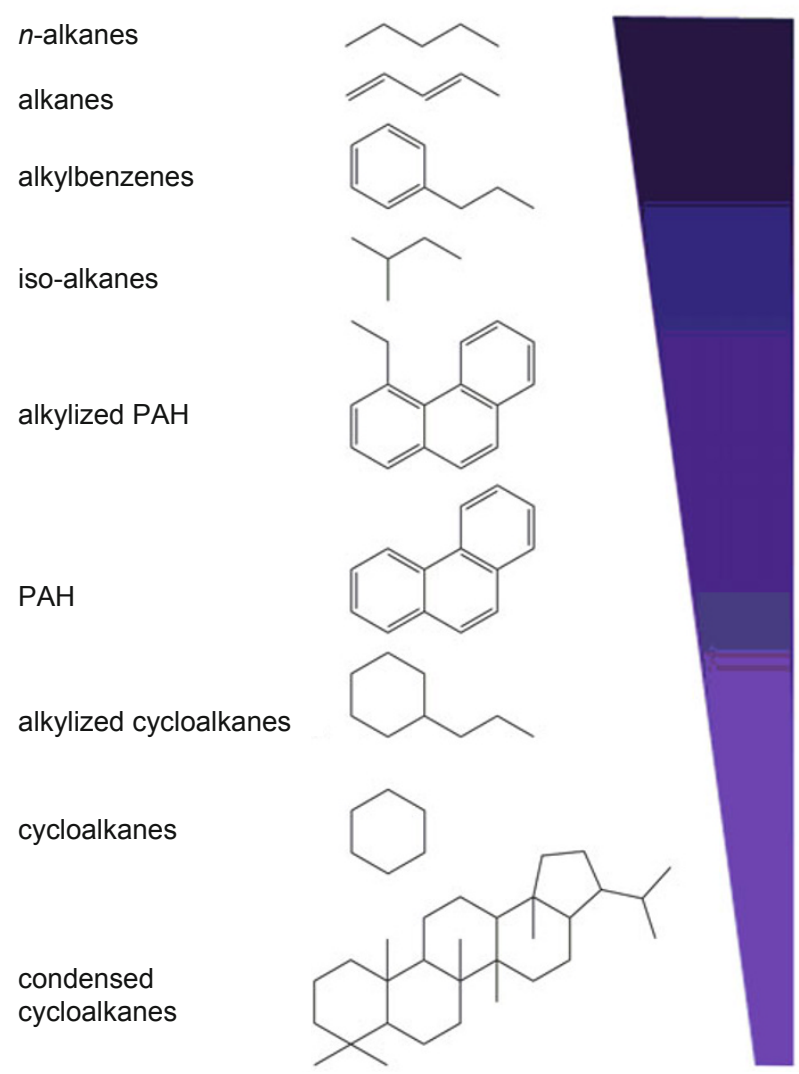

Fig. 7 General biodegradation rates of petroleum hydrocarbons 
where probably nitrogen is a limiting nutrient (Atlas and Bartha, 1998; Atlas, 1995) and oxygen is a predominant factor for aerobic degradation (Venosa et al, 2010), but phosphorus supply instead of others could be a rate-limiting nutrient for subsurface biosphere (Head et al, 2003; Larter et al, 2006; Larter et al, 2003) .

From the view of the length of carbon chain, although longer or shorter chains with carbon atoms up to $36-44$ or less than 10 were reported (Feng et al, 2007; Haines and Alexander, 1974), $n$-alkanes, $n$-alkyl aromatics and aromatic compounds with 10-20 carbons have the lowest bio-toxicity, can be biodegraded easiest. $n$-alkanes and (alkyl) aromatics with 5-6 carbons can be biodegraded in low concentration, but actually most of which are removed via volatilization not by biodegradation. $n$-alkane with $1-4$ carbons with higher bio-toxicity can be biodegraded, but only by some specific microorganisms. The low water solubility of $n$-alkane, alkyl aromatics and aromatic compounds with more than 20 carbons makes them much more difficult be biodegraded.

As far as branched chains are concerned, asphalts with branched chains generally reduce the biodegradation rate, and it is slower for aromatic compounds than that for alkanes. Branched tertiary carbon and quaternary carbon can hinder $\beta$-oxidation. Biodegradation of branched alkanes and cycloalkanes with 10-20 carbons are much more difficult than the corresponding straight-chain homologous series. Biodegradation of cycloalkanes requires synergistic actions of two or more microorganisms. Furthermore, there is higher membrane toxicity of cycloalkanes equal or less than 10 carbon atoms. The biodegradation rate of condensed series of aromatics and cyclic waxes, such as tar oil, bitumen and asphalt which have the components of four or more condensed rings, and some partly oxy-substituted condensed aromatics, is very slow. The mineralization of condensed PAHs, cyclic waxes and high molecular weight alkanes is very slow as well (Englert et al, 1992). The general rate of biodegradation has been shown in Fig. 7 (Steinhart et al, 2001). Peters and Moldwan categorized petroleum hydrocarbons into ten levels according to their biodegradabilities (Peters et al, 2005; Peters and Moldowan, 1995). The bioremediation of spilled oil then should be cautiously based on the properties of oil

Table 7 Biotransformation and reaction types

\begin{tabular}{|c|c|}
\hline Transformation type & Reaction \\
\hline Dehalogenation & $\begin{array}{c}\mathrm{RCH}_{2} \mathrm{Cl} \rightarrow \mathrm{RCH}_{2} \mathrm{OH} ; \mathrm{ArCl}(\mathrm{F}) \rightarrow \mathrm{ArOH} ; \\
\mathrm{ArCl} \rightarrow \mathrm{ArH} ; \mathrm{Ar}_{2} \mathrm{CHCH}_{2} \mathrm{Cl} \rightarrow \mathrm{Ar}_{2} \mathrm{C}=\mathrm{CH}_{2} ; \\
\mathrm{Ar}_{2} \mathrm{CHCHCl}_{2} \rightarrow \mathrm{Ar}_{2} \mathrm{C}=\mathrm{CHCl} ; \mathrm{Ar}_{2} \mathrm{CHCCl} \rightarrow \mathrm{Ar}_{2} \mathrm{C}=\mathrm{CCl}_{2} ; \mathrm{RCCl}_{3} \rightarrow \mathrm{RCOOH} \\
\mathrm{HetCl} \rightarrow \mathrm{HetOH}\end{array}$ \\
\hline Deamination & $\mathrm{ArNH}_{2} \rightarrow \mathrm{ArH}$ \\
\hline Decarboxylation & $\begin{array}{c}\mathrm{ArCOOH} \rightarrow \mathrm{ArH} ; \mathrm{Ar}_{2} \mathrm{CHCOOH} \rightarrow \mathrm{Ar}_{2} \mathrm{CH}_{2} ; \\
\mathrm{RCH}\left(\mathrm{CH}_{3}\right) \mathrm{COOH} \rightarrow \mathrm{RCH}_{2} \mathrm{CH}_{3} ; \\
\mathrm{ArN}(\mathrm{R}) \mathrm{COOH} \rightarrow \mathrm{ArN}(\mathrm{R}) \mathrm{H}\end{array}$ \\
\hline Methoxylation & $\mathrm{RCH}_{3} \rightarrow \mathrm{RCH}_{2} \mathrm{OH}$ and/or $\rightarrow \mathrm{RCHO}$ and/or $\rightarrow \mathrm{RCOOH}$ \\
\hline Hydroxylation and ketogensis & $\begin{array}{c}\mathrm{ArH} \rightarrow \mathrm{ArOH} \\
\mathrm{RCH}_{2} \mathrm{R}^{\prime} \rightarrow \mathrm{RCH}(\mathrm{OH}) \mathrm{R}^{\prime} \text { and } / \mathrm{or} \rightarrow \mathrm{RC}(\mathrm{O}) \mathrm{R}^{\prime} \\
\mathrm{R}\left(\mathrm{R}^{\prime}\right) \mathrm{CHR}^{\prime \prime} \rightarrow \mathrm{R}\left(\mathrm{R}^{\prime}\right) \mathrm{CH}(\mathrm{OH}) \mathrm{R}^{\prime \prime} \\
\mathrm{R}\left(\mathrm{R}^{\prime}\right)\left(\mathrm{R}^{\prime \prime}\right) \mathrm{CCH}_{3} \rightarrow \mathrm{R}\left(\mathrm{R}^{\prime}\right)\left(\mathrm{R}^{\prime \prime}\right) \mathrm{CCH}_{2} \mathrm{OH}\end{array}$ \\
\hline$\beta$-oxidation & $\operatorname{ArO}\left(\mathrm{CH}_{2}\right)_{\mathrm{n}} \mathrm{CH}_{2} \mathrm{CH}_{2} \mathrm{COOH} \rightarrow \mathrm{ArO}\left(\mathrm{CH}_{2}\right)_{\mathrm{n}} \mathrm{COOH}$ \\
\hline Epoxidation & $\mathrm{RCH}=\mathrm{CHR} \rightarrow \mathrm{RCH}-\mathrm{CHR}^{\prime}$ \\
\hline Nitrogen oxidation & $\mathrm{R}\left(\mathrm{R}^{\prime}\right) \mathrm{NR}^{\prime \prime} \rightarrow \mathrm{R}\left(\mathrm{R}^{\prime}\right) \mathrm{N}(\mathrm{O}) \mathrm{R}^{\prime \prime}$ \\
\hline Sulfur oxidation, $=\mathrm{S}$ to $=\mathrm{O}$ & $\begin{aligned} \mathrm{RSR}^{\prime} & \rightarrow \mathrm{RS}(\mathrm{O}) \mathrm{R}^{\prime} \text { and } / \mathrm{or} \rightarrow \mathrm{RS}\left(\mathrm{O}_{2}\right) \mathrm{R}^{\prime} \\
(\mathrm{AlkO})_{2} \mathrm{P}(\mathrm{S}) \mathrm{R} & \rightarrow(\mathrm{AlkO})_{2} \mathrm{P}(\mathrm{O}) \mathrm{R} ; \mathrm{RC}(\mathrm{S}) \mathrm{R}^{\prime} \rightarrow \mathrm{RC}(\mathrm{O}) \mathrm{R}^{\prime}\end{aligned}$ \\
\hline Sulfoxide reduction & $\mathrm{RS}(\mathrm{O}) \mathrm{R}^{\prime} \rightarrow \mathrm{RSR}^{\prime}$ \\
\hline Alkyne reduction & $\mathrm{RC} \equiv \mathrm{CH} \rightarrow \mathrm{RCH}=\mathrm{CH}_{2}$ \\
\hline Alkene reduction & $\begin{aligned} \mathrm{Ar}_{2} \mathrm{C} & =\mathrm{CH}_{2} \\
\mathrm{Ar}_{2} \mathrm{C} & \rightarrow \mathrm{Ar}_{2} \mathrm{CHCH}_{3} \\
& \rightarrow \mathrm{Ar}_{2} \mathrm{CHCH}_{2} \mathrm{Cl}\end{aligned}$ \\
\hline Double bond hydration & $\mathrm{Ar}_{2} \mathrm{C}=\mathrm{CH}_{2} \rightarrow \mathrm{Ar}_{2} \mathrm{CHCH}_{2} \mathrm{OH}$ \\
\hline Nitro metabolism & $\begin{array}{l}\mathrm{RNO}_{2} \rightarrow \mathrm{ROH} \\
\mathrm{RNO}_{2} \rightarrow \mathrm{RNH}_{2}\end{array}$ \\
\hline Oxime metabolism & $\mathrm{RCH}=\mathrm{NOH} \rightarrow \mathrm{RC}=\mathrm{N}$ \\
\hline Nitrile-amine metabolism & $\mathrm{RC}=\mathrm{N} \rightarrow \mathrm{RC}(\mathrm{O}) \mathrm{NH}_{2}$ and $/ \mathrm{or} \rightarrow \mathrm{RCOOH}$ \\
\hline Organotin & $\mathrm{R}_{3} \mathrm{SnOH} \rightarrow \mathrm{R}_{2} \mathrm{SnO} \rightarrow \mathrm{RSnO}_{2} \mathrm{H}$ \\
\hline Organomercuricals & $\mathrm{RHgR}^{\prime} \rightarrow \mathrm{RH}$ and/or Hg \\
\hline
\end{tabular}


and microorganisms with corresponding enzymes.

In addition to normal hydrocarbons, there are many kinds of additives in oil products, especially as presently the production wells of most countries in the world have reached to their middle or late stages. In order to enhance their recoveries, lots of different additives have been unscrupulously/versatilely added in, for examples multifunctional detergents, anti-icing additives, dispersants, flow improvers, pour point depressants (pour point reducers), antioxidants, corrosion inhibitors, octane improvers, antiknock agents, combustion improvers, antistatic agents, antimicrobial agents, dyes, dehydrators, and agglomerating agents and so on. All these additives have multitudinous chemical components and structures. Luckily, however, there are lots of bacteria and fungi in soil which can bio-transform those additives to a certain extent. Organically functional fragments found in nature so far known to be bio-transformed are listed in Table 6 and Table 7 (Englert et al, 1992; Wackett and Hershberger, 2001; Wan, 2011b), but which may be only parts of our ignorance-enlarging universe.

Abbreviation: $\mathrm{R}$ (including those $\mathrm{R}_{1}, \mathrm{R}_{2}, \mathrm{R}_{3}$ with same or different groups)-organic fragment; Ar-aryl group; Alk-alkyl group; Het-heterocyclic group; X-halogen atom. Partly bound with UCM. The abbreviations in Table 7 are same with these.

Comprehensively, as seen in Tables 6 and 7, to date, linkages found to be enzymatically cleaved by microorganisms include ester bonds, $\mathrm{C}-\mathrm{N}$ bonds, $\mathrm{C}-\mathrm{S}$ bonds, $\mathrm{C}-\mathrm{Hg}$ bonds, $\mathrm{C}-\mathrm{Sn}$ bonds, $\mathrm{C}-\mathrm{O}-\mathrm{P}$ bonds, $\mathrm{P}-\mathrm{S}$ bonds, $\mathrm{S}-N$ bonds, $\mathrm{S}-\mathrm{S}$ bonds, sulfonic esters, polypeptides and carbamates. The reaction types involved are methylation, etherification, $N$-acylation, nitration, $N$-nitrosification and dipolymer reaction (such as RSH produces RSSR) (Englert et al, 1992; Wackett and Hershberger, 2001; Wan, 2011b). Microbial diversity is such that presently only $10 \%$ or less is recognized (Whitman et al, 1998), so much more new fragments and reaction types (Heider, 2007) will be identified in future.

\section{Perspectives}

Although petroleum pollution of waters, such as oil spills and oil-well explosions, has widely led to public consideration and debate, the problems of petroleumcontaminated soil/sediments are less investigated and clarified. Recently anaerobic biodegradation of petroleum has been recognized and made a little progress (Jones et al, 2008; Lovley, 2001), however, most investigations reported in the literature in the past half century have been focused on or limited to aerobic degradation. No research has systematically considered and investigated the impacts of environmental conditions, especially in-site temperature, $\mathrm{pH}$, oxidationreduction potential (Eh), surface and subsurface hydrology, on aerobic degradations.

As a most complex mixture, petroleum pollutants represent a very difficult challenge (Du et al, 2011). For example, even after 20 years, and in spite of a great deal of human effort and millions and billions of money investment, the fishery and wild animals in the Prince William Sound have not recovered from the pollution caused by the massive oil spill of Exxon Valdez oil tanker (Raloff, 2009; WWFUS, 2009) and are still being exposed to it (Esler et al, 2010) although it is the largest and most thoroughly studied case (Atlas and Bartha, 1998; Atlas, 1995). As above mentioned, researchers put emphasis on some parts of petroleum, i.e., normal alkanes, cyclic hydrocarbons, arenes and aromatics those are easiest to be analyzed. The residual portions of petroleum, such as non-hydrocarbons (NOS-containing compounds), asphaltene and UCM, are less determined and analyzed, not to mention their biodegradation and mechanisms. However it should be pointed out that, in our opinion, it is not enough for microbes alone to deal with these matters. It is a top priority and scientists must work together with various methods, , to tackle it most urgently.

\section{Acknowledgements}

We are grateful to our colleagues. They are included, but not limited to, TG. Wang, F. Hao, Q. Zhang, and Z. Xu. Steve Larter, Haiping Huang and Thomas Oldenburg, University of Calgary, are greatly appreciated for their great help on WYY. We acknowledge supports from the New Century Excellent Talents in University of Ministry of Education (NCET-090765), the China Scholarship of Council (2009644509), and the Natural Scientific Funds of China (40973064).

\section{References}

Agathos S and Reineke W. Biotechnology for the environment: Soil remediation. In Hofman $\mathrm{M}$, ed. Focus on Biotechnology Ser. Dordrecht. Kluwer Academic Publishers. 2002

Aitken C M, Jones D M and Larter S R. Anaerobic hydrocarbon biodegradation in deep subsurface oil reservoirs. Nature. 2004. 431(7006): 291-294

Atlas R. Microbial degradation of petroleum hydrocarbons: An environmental perspective. Microbiological Reviews. 1981. 45(1): 180-209

Atlas R. Petroleum Microbiology. New York: Macmillan Publishing Company. 1984

Atlas R and Bartha R. Microbial Ecology: Fundamentals and Applications. Menlo Park, CA: Benjamin Cummings Science Publishing. 1998

Atlas R M. Petroleum biodegradation and oil spill bioremediation. Marine Pollution Bulletin. 1995. 31(4 12): 178-182

Barlow L and Philp J. Suspicions to solutions: Characterizing contaminated land. In Atlas R and Philp J, eds. Bioremediation: Applied Microbial Solutions for Real-World Environmental Cleanup. Washington, DC: ASM Press. 2005. 49-85

Boopathy R. Factors limiting bioremediation technologies. Bioresource Technology. 2000. 74(1): 63-67

Calabrese E and Kostecki P. Principles and Practices for Petroleum Contaminated Soils. In: CRC Press. 1992

Cerniglia C. Microbial transformation of aromatic hydrocarbons. In Atlas R, ed. Petroleum Microbiology. New York: Macmillan Publishing Company. 1984. 99-128

Chaineau C H, Morel J, Dupont J, et al. Comparison of the fuel oil biodegradation potential of hydrocarbon-assimilating microorganisms isolated from a temperate agricultural soil. The Science of The Total Environment. 1999. 227(2-3): 237-247

Chaineau C H, Morel J L and Oudot J. Microbial degradation in soil microcosms of fuel oil hydrocarbons from drilling cuttings. Environmental Science and Technology. 1995. 29(6): 1615-1621

Chen J. Environmental Protection of Petroleum and Petrochemical 
Industries: An Introduction. Beijing: Petroleum Industry Press. 2005 (in Chinese)

Clemente J and Fedorak P. A review of the occurrence, analyses, toxicity, and biodegradation of naphthenic acids. Chemosphere. 2005. 60(5): 585-600

CMEP (China Ministry of Environmental Protection) and NDRC (National Development and Reform Commission). National Hazardous Waste Inventory. 2008/[2008-08-15]. http://www.zhb. gov.cn/info/bgw/b1/200806/t20080617_124095.htm

Cookson J. Bioremediation Engineering: Design and Application. New York: McGraw-Hill Book Company. 1995

Du W, Wan Y, Zhong N, et al. Current status of petroleum-contaminated soils and sediments. Journal of Wuhan University (Science Edition). 2011. 57(4): 311-322 (in Chinese)

Englert C, Kenzie E and Dragun J. Bioremediation of petroleum products in soil. In Calabrese E and Kostecki P, eds. Principles and Practices for Petroleum Contaminated Soils. Chelsea, MI.: Lewis Publishers. 1992. 111-129

Esler D, Trust K A, Ballachey B E, et al. Cytochrome P4501A biomarker indication of oil exposure in harlequin ducks up to 20 years after the Exxon Valdez oil spill. Environmental Toxicology And Chemistry. 2010. 29(5): 1138-1145

Fass R, Flashner Y and Reuveny S. Novel Approaches for Bioremediation of Organic Pollution. New York: Kluwer Academic/ Plenum Publishers. 1999

Feng L, Wang W, Cheng J, et al. Genome and proteome of long-chain alkane degrading Geobacillus thermodenitrificans NG80-2 isolated from a deep-subsurface oil reservoir. Proceedings of the National Academy of Science of the United States of America. 2007. 104(13): 5602-5607

Haines J R and Alexander M. Microbial degradation of high-molecularweight alkanes. Applied Microbiology. 1974. 28(6):1084-1085

He F P, Zhang Z H, Wan Y Y, et al. Polycyclic aromatic hydrocarbons in soils of Beijing and Tianjin region: Vertical distribution, correlation with TOC and transport mechanism. Journal of Environmental Sciences. 2009. 21(5): 675-685

He Z, Li Z and Ji G. Surfactant enhanced washing of aged oilcontaminated soil. Environmental Pollution and Control. 2006. 28(12): 884-887 (in Chinese)

Head I M, Jones D M and Larter S R. Biological activity in the deep subsurface and the origin of heavy oil. Nature. 2003. 426(6964): 344-352

Heider J. Adding handles to unhandy substrates: anaerobic hydrocarbon activation mechanisms. Current Opinion In Chemical Biology. 2007. 11(2): 188-194

Jin Z. Biodegradation of Pollutants. Shanghai: East China University of Science and Technology Press. 1997 (in Chinese)

Jones D, Head I, Gray N, et al. Crude-oil biodegradation via methanogenesis in subsurface petroleum reservoirs. Nature. 2008. 451(7175): 176-180

Korda A, Santas P, Tenente A, et al. Petroleum hydrocarbon bioremediation: Sampling and analytical techniques, in situ treatments and commercial microorganisms currently used. Applied Microbiology and Biotechnology. 1997. 48(6): 677-686

Kostecki P and Calabrese E. Petroleum Contaminated Soils: Remediation Techniques, Environmental Fate, and Risk Assessment. Chelsea, Michigan: Lewis Publishers. 1988

Larter S, Huan H, Adams J, et al. The controls on the composition of biodegraded oils in the deep subsurface-Part II: Geological controls on subsurface biodegradation fluxes and constraints on reservoirfluid property prediction. AAPG Bulletin. 2006. 90(6): 921-938

Larter S, Wilhelins A, Head I, et al. The controls on the composition of biodegraded oils in the deep subsurface - part I: Biodegradation rates in petroleum reservoirs. Organic Geochemistry. 2003. 34(4): 601-613
Li L, Zhang L and Zhang Y. Research introduction of microorganisms of petroleum hydrocarbon degradation. Microorganism Bulletin. 2001a. 28(5): 89-92 (in Chinese)

Li G and Feng S. Petroleum Microbiology. Shanghai: Shanghai Jiaotong University Press. 1991 (in Chinese)

Li J, Ma H, Xia X, et al. Soil vapor extraction technology for soil pollution of organic compounds and its research advances. Techniques and Equipment For Environmental Pollution Control. 2001b. 2(4): 3948 (in Chinese)

Liang S, Wang X and Shan B. Development of biosurfactant-enhanced biodegradation of hydrophobic organic pollutants. Environmental Protection of Chemical Industry. 2005. 25(4): 276-280 (in Chinese)

Liu X, Liu J and Zhang N. Discussion on innocuous treatment of oil sludge in oil-gas field. Environmental Protection of Oil and Gas Fields. 2004. 14(2): 32-35 (in Chinese)

Lovley D R. Bioremediation - Anaerobes to the rescue. Science. 2001. 293(5534): 1444-1446

Miehlich G. Do contaminated soils have to be decontaminated? In Stegmann R, Brunner G, Calmano W, Matz G, eds. Treatment of contaminated Soil: Fundamentals, Analysis, Application. Berlin, Heidelberg, New York: Springer. 2001. 15-19

NIH and NLM. Crude Oil Spills and Health. 2010/[2010-12/15]. http:// sis.nlm.nih.gov/dimrc/oilspills.html\#a8

Perry J. Microbial metabolism of cyclic alkanes. In Atlas R, ed. Petroleum Microbiology. New York: Macmillan Publishing Company. 1984. 61-97

Peters K and Moldowan J. The Biomarker Guide: Interpreting Molecular Fossils in Petroleum and Ancient Sediments. Beijing: Petroleum Industry Press. 1995

Peters K, Walters C and Moldowan J. The Biomarker Guide, Volume 2: Biomarkers and Isotopes in the Petroleum Exploration and Earth History. Cambridge: Cambridge University Press. 2005

Philp J. Environmental pollution and restoration: A role for bioremediation. In Atlas R and Philp J, eds. Bioremediation: Applied Microbial Solutions for Real-World Environmental Cleanup. Washington, DC: ASM Press. 2005. 1-48

Pointing S B. Feasibility of bioremediation by white-rot fungi. Applied Microbiology and Biotechnology. 2001. 57(1-2): 20-33

Qi Y and Wang H. Study progress on bioremediation of soil oil pollution. Shanghai Environmental Science. 2002. 21(3): 177-180 (in Chinese)

Raloff J. Exxon Valdez 20 Years Later Series: Effects of the Exxon Valdez oil spill linger. 2009/[2009-10-29]. http://www.sciencenews. org/view/generic/id/42159/title/Exxon_Valdez_20_Years_Later

Robertson S J, McGill W B, Massicotte H B, et al. Petroleum hydrocarbon contamination in boreal forest soils: A mycorrhizal ecosystems perspective. Biological Reviews of the Cambridge Philosophical Society. 2007. 82(2): 213-240

Roling W, Head I M and Larter S R. The microbiology of hydrocarbon degradation in subsurface petroleum reservoirs: perspectives and prospects. Research In Microbiology. 2003. 154(5): 321-328

Rulkens W. An overview of soil and sediment treatment research in the Netherlands. In Stegmann R, Brunner G, Calmano W, Matz G, eds. Treatment of Contaminated Soil: Fundamentals, Analysis, Application. Berlin, Heidelberg, New York: Springer. 2001. 21-36

Semple K, Cain R and Schmidt S. Biodegradation of aromatic compounds by microalgae. Fems Microbiology Letters. 1999. 170: 291-300

Shen P. Microbiology. Beijing: China Higher Education Press. 2000 (in Chinese)

Singer M and Finnerty W. Microbial metabolism of straight-chain and branched alkanes. In Atlas R, ed. Petroleum Microbiology. New York: Macmillan Publishing Company. 1984. 1-59

Stegmann R, Brunner G, Calmano W, et al. Treatment of Contaminated Soil: Fundamentals, Analysis, Application. Berlin, Heidelberg, New 
York: Springer. 2001

Steinhart H, Kacker T, Meyer S, et al. How much analytical work do we need? In Stegmann R, Brunner G, Calmano W, Matz G, eds. Treatment of Contaminated Soil: Fundamentals, analysis, application. Berlin, Heidelberg, New York: Springer. 2001. 37-47

Su R G, Mu B Z, Wang X L, et al. Biodegradation mechanism and affecting factors of petroleum hydrocarbons. Environmental Protection of Chemical Industry. 2001. 21(4): 205-208 (in Chinese)

Su Y H and Yang X Y. Interactions between selected PAHs and the microbial community in rhizosphere of a paddy soil. Science of the Total Environment. 2009. 407(3): 1027-1034

Sui H, Ru X, Huang G Q, et al. The evolution of bioventing remediation for petroleum-contaminated soils. Ecology and Environment. 2003. 12(2): 216-219 (in Chinese)

Sun N, Guan J and Bai L. Research on integration utilization technique of solid waste containing crude oil. Techniques and Equipment for Environmental Pollution Control. 2003. 4(6): 67-69 (in Chinese)

Toyama T, Furukawa T, Maeda N, et al. Accelerated biodegradation of pyrene and benzo[a]pyrene in the Phragmites australis rhizosphere by bacteria-root exudate interactions. Water Research. 2011. 45(4): $1629-1638$

USACE (US Army Corps of Engineers). Engineering and Design -Soil Vapor Extraction and Bioventing. Publication Number: EM 1110-14001. 2002/[2010-06-18]. http://140.194.76.129/publications/engmanuals/em1110-1-4001/toc.htm

USEPA (United States Environmental Protection Agency). Remediation Technology Cost Compendium - Year 2000. EPA 542-R-2001/ [2008-06-13]. http://www.epa.gov/tio/download/remed/542r01009. pdf

USEPA (United States Environmental Protection Agency). Nationally Significant Incidents. 2009/[2010-06-20]. http://www.epa.gov/ emergencies/content/learning/national_response.htm

van Hamme J and Singh A, Ward O. Recent advance in petroleum microbiology. Microbiology And Molecular Biology Reviews. 2003. 67(4): 503-549

Venosa A D, Campo P and Suidan M T. Biodegradability of lingering crude oil 19 years after the Exxon Valdez oil spill. Environmental Science and Technology. 2010. 44(19): 7613-7621

Wackett L and Hershberger C. Biocatalysis and biodegradation: microbial transformation of organic compounds. Washington, D.C.: ASM Press. 2001

Walker J, Colwell R and Petrakis L. Degradation of petroleum by an alga, Prototheca zopfii. Applied Microbiology. 1975. 30(1): 79-81

Wan Y. Bioconcentration, biocatalysis and biodegradation. In Wan Y, ed. Organic Pollution Prevention and Control. Beijing: Petroleum Industry Press. 2011a. 38-57 (in Chinese)

Wan Y. Organometallic pollution. In Wan Y, ed. Organic Pollution Prevention and Control. Beijing: Petroleum Industry Press. 2011b. 122-149 (in Chinese)

Wang J and Wen X. Modern Environmental Biotechnology. Beijing: Qinghua Daxue Press. 2000 (in Chinese)

Ward O P. The industrial sustainability of bioremediation processes. Journal of Industrial Microbiology. 2004. 31(1): 1-4

Whitman W B, Coleman D C and Wiebe W J. Prokaryotes: the unseen majority. The Proceeding of the National Academy of Science of the United States of America. 1998. 95(12): 6578-6583

WWF-US (World Wildlife Fund in United States). Lessons not learned: 20 years after the Exxon Valdez disaster. 2009/[2010-06-18]. http://assets.wwf.ca/downloads/wwf_20yearsafter_exxon.pdf

Xia P, Li X and Liu B. Biological remediation of oil pollution. Pollution Control Technology. 2006. 19(3): 37-40 (in Chinese)

(Edited by Zhu Xiuqin) 